\title{
Alan Archibald Campbell-Swinton (1863-1930) Electrical engineer
}

\author{
Richard F. Mould
}

Alan Archibald Campbell-Swinton was an electrical engineer, holding memberships of the Institutes of Civil Engineering, Electrical Engineering and Mechanical Engineering; as well being a Fellow of the Royal Society. He was also one of the early non-medical X-ray experimenters and is notable for producing the first X-ray image in the United Kingdom, on 8 January 1896. He was active in the Röntgen Society of London and became its President in 1911-1912. One of his major interests was the theory of television production. Campbell-Swinton ended his scientific career as a consulting engineer in London. This brief biography gives special reference to Campbell-Swinton's work with X-rays.

Key words: X-ray imaging in 1896, X-ray tube design, electric lighting, television theory, Turbinia, Röntgen Society, Royal Society, Nature, William George Armstrong, Charles Parsons, Gugliemo Marconi, Lord Salisbury, King Edward VII, Royal Photographic Society

\section{Introduction}

Alan Archibald Campbell-Swinton (1863-1930), Figure 1 , was an electrical engineer, born in Scotland, who was involved in the early theories of television. He had no university or college training and passed no examinations but still managed to be a Fellow of the Royal Society, elected in 1915: a unique achievement in that era of which he was justifiably proud. He was also one of the early non-medical $X$-ray experimenters and is notable for producing the first X-ray images worldwide after Röntgen, on 8 January 1896. Campbell-Swinton is mentioned many times in the 1896 issues of the journal Nature. He ended his scientific career as a consulting engineer in London.

\section{Education and apprenticeship, Edinburgh \& Newcastle 1863-1887}

Alan Archibald Campbell-Swinton was born in 1863 in Edinburgh and grew up on the family estate in Kimmerghame, Berwickshire and was educated at Cargilfield Trinity School, Edinburgh, and Fettes College 1878-1881. At an early age of 15 , in 1878 , he understood the principles of photography, built his own camera and prepared his own light-sensitive photographic paper.

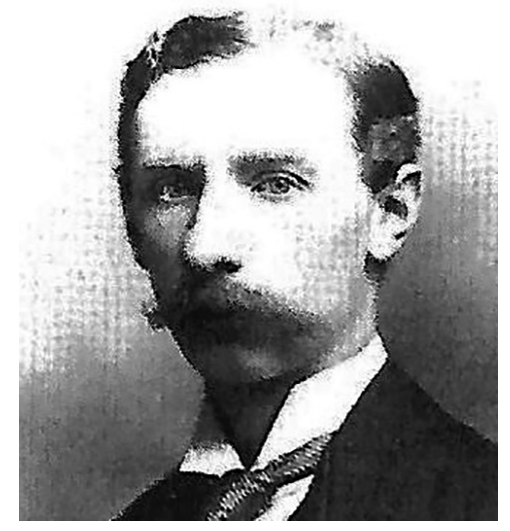

Figure 1. Campbell-Swinton as a young man

He was the third son of Archibald Campbell-Swinton, professor of civil law in the University of Edinburgh, and his wife Georgiana Caroline Sitwell. His Father was also Brigadier-General of the Company of Archers in Scotland. Alan Archibald never married.

In 1881 he went to Le Havre to study French and mathematics and visited the Paris Exhibition where he was impressed by the electrical inventions. On his return in 1882 he started an apprenticeship in Sir William George Armstrong's engineering 
Newcastle works in Elswick-on-Tyne. He introduced lead-covered wires and cables for electrical wiring in ships and in 1883 published a book The Principles and Practice of Electric Lighting. He completed his apprenticeship in 1887 and then moved to London to set up his own consultancy business [1, 2].

\section{Electrical contractor \& consulting engineer, London 1887-1926}

In 1887 Campbell-Swinton carried out electric lighting installations in many country houses and was connected with several of the earliest electric supply companies, especially those which employed steam turbines. For example he was a director of the Scarborough Electric Supply Company and the Cambridge Electric Supply Company.

This work included the early development of the steam turbine and aiding Charles Parsons (1854-1931) in the construction of the torpedo boat destroyer Turbinia. It was completed in 1894. In 1897 he was one of the crew which gatecrashed the Spithead Review to mark Queen Victoria's Diamond Jubilee. The Turbinia reached speeds of 34 knots compared to the top speed for destroyers of 27 knots [3].

Campbell-Swinton also aided Guglielmo Marconi in obtaining an audience for his telegraphic invention by sending a letter of introduction to the Chief Engineer of the British Post Office, William Henry Preece, who in 1896 invited Marconi to give a demonstration. His consulting rooms were at 66, Victoria Street, Westminster SW1 and his home was at 40, Chester Square, London SW1. He retired from practice in in Victoria Street in 1926 but continued withy a few special consultancies in Chester Square [4].

\section{Television theory 1903-1928}

Around 1903 he began to experiment with cathode ray tubes for the electronic transmission and reception of images and provided the theoretical basis for electronic television two decades before the technology existed to implement it $[2,5]$. He described this theoretical basis in a 1908 letter to Nature [5]. In the August 1915 issue of the magazine Electrical Experimenter his work was popularised as the "Campbell-Swinton Electronic Scanning System" [2].

He also described this work in his 1911-1912 Röntgen Society Presidential Address, published in the Journal of the Röntgen Society, [7] and in the June 1928 issue of Modern Wireless under the title"Television by Cathode Rays". The basic cathode ray tube was a large vacuum tube with a long neck on one end and a flat screen on the other. An electron gun in the neck could shoot a stream of electrons towards the flat end of the tube which was covered with an internal coating of light-emitting phosphor. Campbell-Swinton argued that by scanning or sweeping the electron stream back and forth in rows from top to bottom while varying the intensity of the electronic stream, a moving image could be drawn [7, 8]. He did not patent his ideas.

\section{X-rays 1896}

Röntgen discovered X-rays on 8 November 1895 and on 1 January 1896 wrote to scientific colleagues enclosing some example radiographs, each marked with the stamp "Physik Institut der Universität Würzburg". The first newspaper account was from Vienna on 5 January 1896 in Die Presse, and the first account in the British press was on 6 January 1896 in the Daily Chronicle. The first radiographs to be taken after those produced by Röntgen's were in the United Kingdom on 8 January 1896 by Campbell-Swinton, of which two are shown in Figure 2. These were of various objects exposed through an aluminium screen.
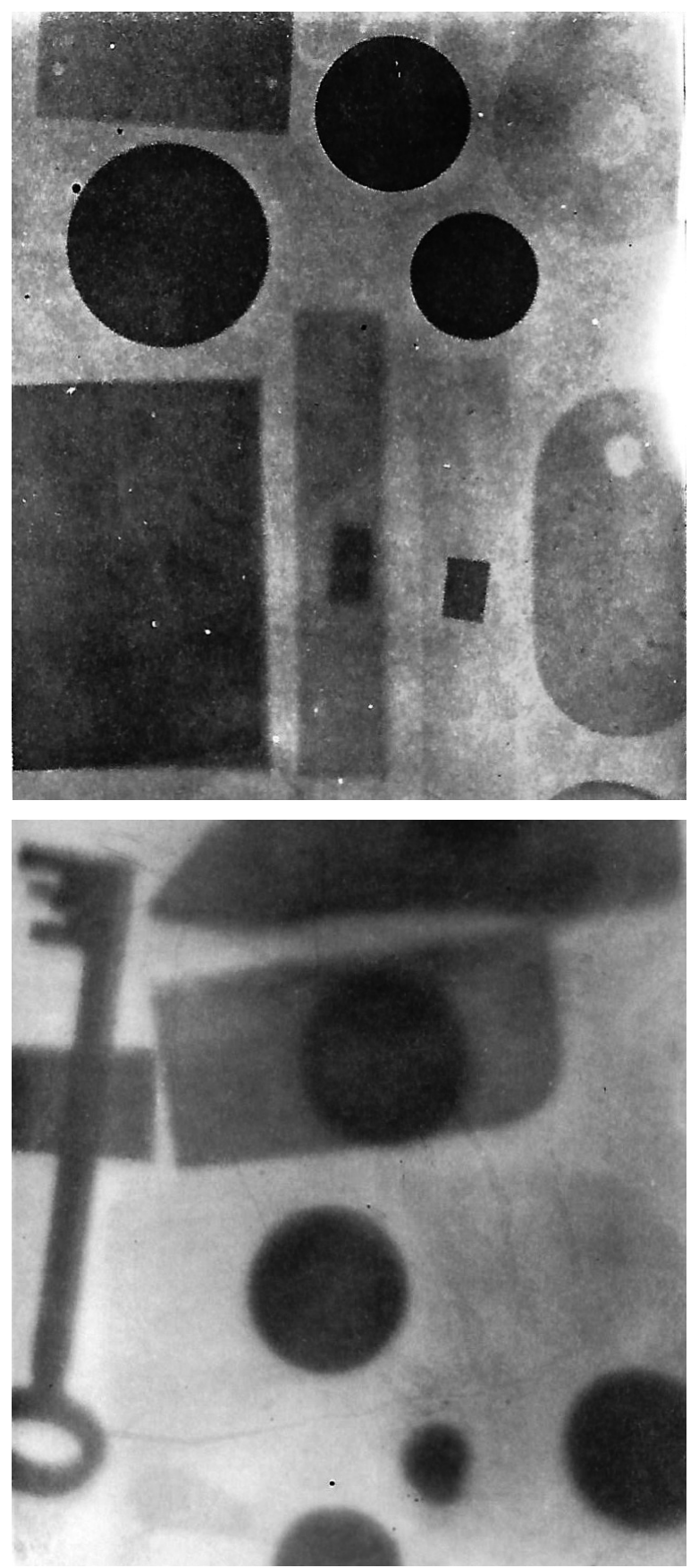

Figure 2. Two radiographs taken by Campbell-Swinton on 8 January 1896 (Courtesy Science Museum, South Kensington, London) 
Campbell-Swinton is also credited with being the first after Röntgen to make a radiograph of human anatomy: his own hand. This was taken on 13 January and exhibited at the Camera Club, London, on 16 January. It was an image of poor quality with the only skeletal parts seen being the top two joints of the fingers: exposure time was 20 minutes. Image quality improved rapidly in the early months of 1896 and Figure 3 shows the hand of a former British Prime Minister, Lord Salisbury (1830-1903), taken in May 1896 by Campbell-Swinton. However, not everyone found the new imaging process of interest. One response in the 1896 Pall Mall Gazette stated: "We are sick of the röntgen rays... you can see other people's bones with the naked eye, and also see through 8 inches of solid wood. On the revolting indecency of this there is no need to dwell." It is also recorded that when King Edward VII (1841-1910) views a radiograph his comment was "How disgusting!"

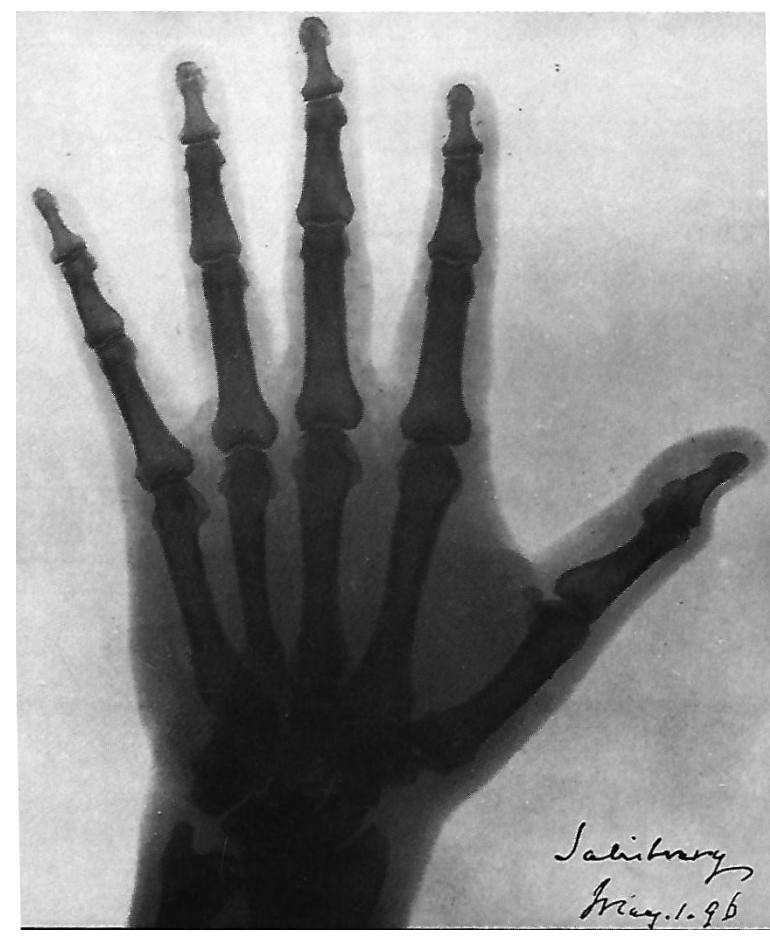

Figure 3. Radiograph of the hand of Lord Salisbury

The photograph in Figure 4 was taken during a lecture-demonstration of X-rays before the Royal Photographic Society on 11 February 1896 [1, 9]. Campbell-Swinton is standing and the man seated is probably J.C.M. Stanton. The $X$-ray tube in use and the diagram on the white paper screen show a pear-shaped tube of the type used by Röntgen to make his discovery, the target being the wide end of the glass tube. Positioning of the tube is made using a wooden retort stand... and a pile of books!

During 1896 probably some 250 different designs of X-ray tube were made worldwide. However, of these the

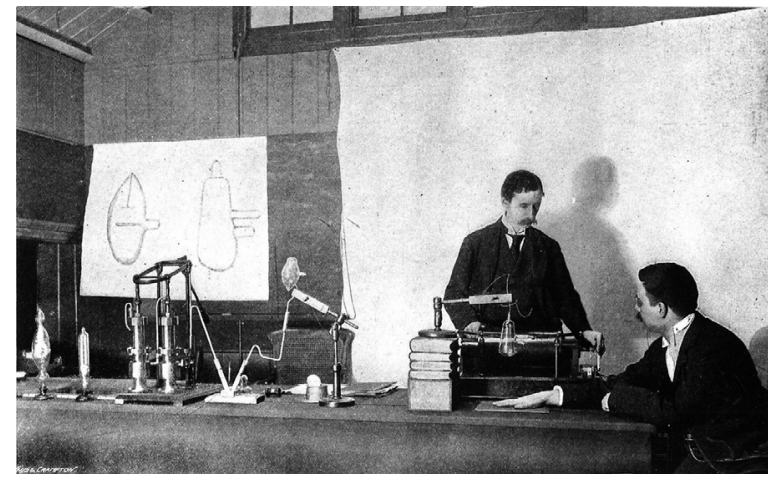

Figure 4. Campbell-Swinton demonstrating X-ray imaging of a hand. 11 February 1896

two most important designed features adopted were the introduction of a sheet of platinum into the tube to serve as a metal target, Figure 5, and a concave cathode to focus the electrons onto a small area of the metal target. This latter improvement was made by Herbert Jackson (1863-1936) of King's College, London, in May 1896 [10] and by Sir William Crookes (1832-1919) [11]. Another Campbell-Swinton design of an X-ray tube is shown in Figure 6 and is described in the historical collection of the British Institute of Radiology [12] as "a tube for alternating currents, 1896. 8 inches long." The original pear-shaped X-ray tube used by Röntgen was 13 inches in length.

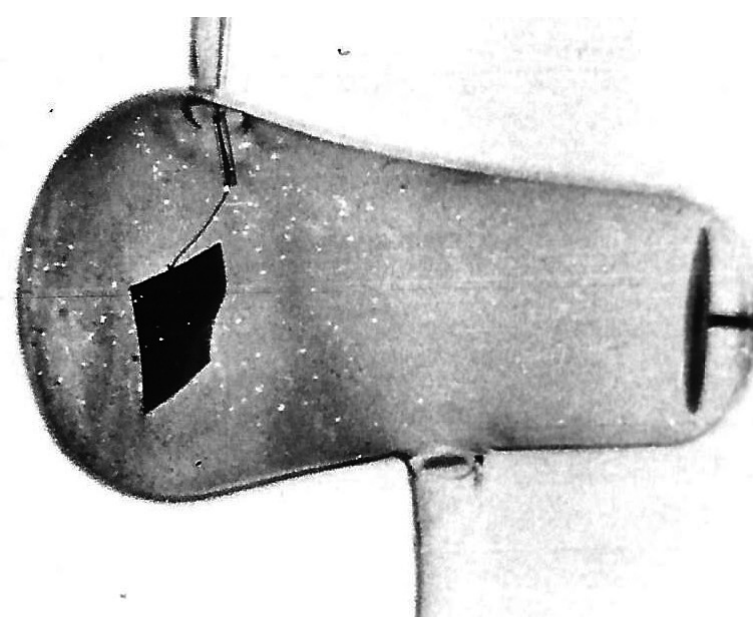

Figure 5. Campbell-Swinton's design of an X-ray tube with a metal target

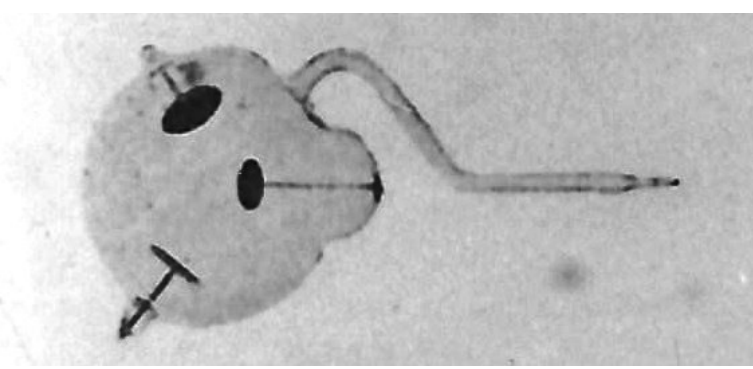

Figure 6. X-ray tube designed by Campbell-Swinton. By the time this tube was available, the pear-shaped glass bulb had been abandoned 


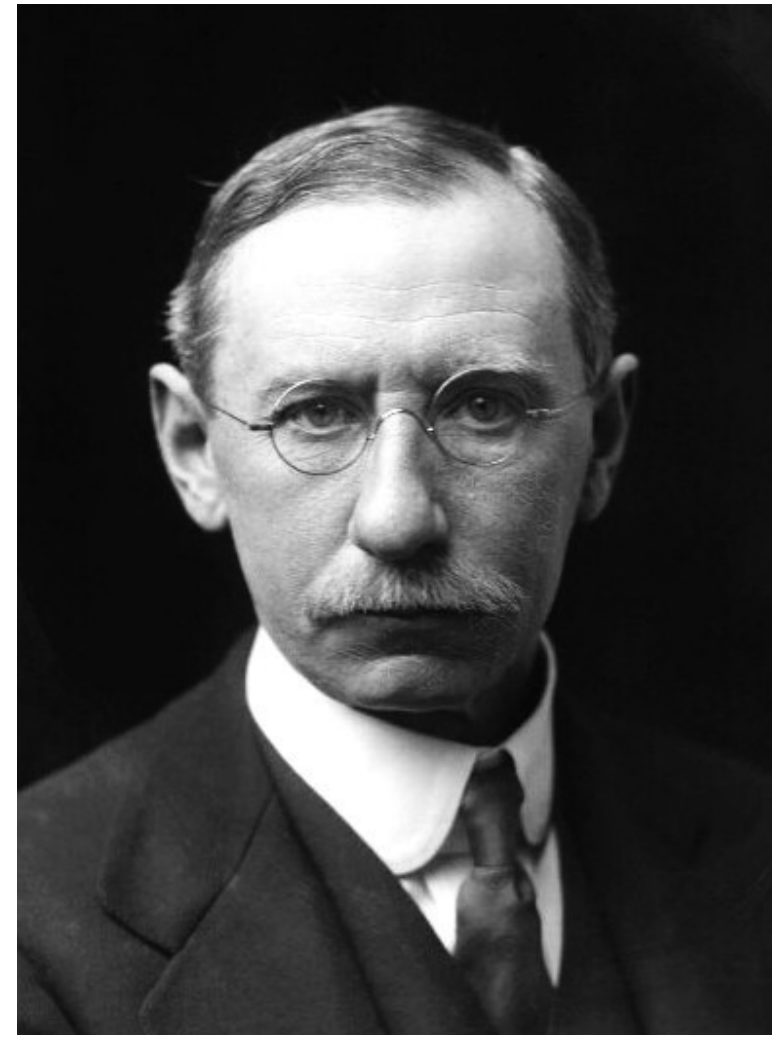

Figure 7. Campbell-Swinton in later years (Courtesy National Portrait Gallery)

\section{Society Memberships, Fellowships \& Presidencies}

Royal Institution. Associate 1886, Membership 1890, Vice-President 1921-1925. Memberships of the Institutes of Civil Engineering, Electrical Engineering and Mechanical Engineering. Fellow of the Royal Society. Member of the first
Council of the Röntgen Society. President of the Röntgen Society 1911-1912. President of the Radio Society of Great Britain. Member of the General Board and Executive Committee of the National Physical Laboratory. Vice-President and Chairman of the Council of the Royal Society of Arts. Campbell-Swinton is shown in his later years in Figure 7.

\section{Conflict of interest: none declared}

\section{Richard F. Mould, MSc, PhD}

4, Town End Meadow

Cartmel

Grange-over-Sands

Cumbria LA116QG

United Kingdom

e-mail: manorroadsouthport@yahoo.co.uk

Received \& Accepted: 4 Mar 2018

\section{References}

1. Burrows EH. Pioneers and Early Years a History of British Radiology. Alderney: olophon, 1986.

2. https://en.wikipedia.org/wiki/Alan_Archibald_Campbell-Swinton.

3. http://www.dunsehistorysociety.co.uk/swinton.shtml.

4. https://www.gracesguide.co.uk/Alan_Archibald_Campbell_Swinton.

5. Burns RW. Television: an International History of the Formative Years. London: Institute of Electrical Engineers (History of Technology Series), 1998

6. Campbell-Swinton AA. Distant electric vision. Nature June 1908: 78; 151.

7. Campbell-Swinton AA. Presidential address. J Röntgen Soc January 1912: 8: 1-13

8. http://www.bairdtelevision.com/swinton.html.

9. Ward Snowden H. Marvels of the new light. Notes on the Röntgen rays. Windsor Magazine April 1896: 3; 372-384

10. Jackson H. Note on focus tube for X-rays. Elec Review (London) 13 March 1896: 38; 340.

11. Mould RF. Sir William Crookes (1832-1919) biography with special reference to X-rays. Nowotwory J Oncol 2017: 67; 79-88.

12. Mould RF. The British Institute of Radiology Collection of X-ray tubes, lantern slides, journals and books. Br Inst Radiology Bulletin 1979: 5; 3. 